\title{
Analysis of clinical manifestations, risk factors and diagnostic procedures in children with urolithiasis
}

\author{
Analiza objawów klinicznych, czynników ryzyka oraz postępowania diagnostycznego \\ u dzieci z kamicą układu moczowego
}

\author{
'Student Research Group at the Department of Paediatrics, Collegium Medicum, University of Zielona Góra, Zielona Góra, Poland \\ ${ }^{2}$ Clinical Department of Paediatrics, University Hospital, Zielona Góra, Poland \\ ${ }^{3}$ One-Day Department of Paediatric Urology, Wiśniowa Clinic, Zielona Góra, Poland \\ ${ }^{4}$ Department of Paediatrics, Collegium Medicum, University of Zielona Góra, Zielona Góra, Poland \\ \# Equally contributed to this work. \\ Correspondence: Associate Professor Marcin Zaniew, MD, PhD, Department of Paediatrics, Collegium Medicum, University of Zielona Góra, Zyty 28, 65-046 Zielona Góra, Poland, e-mail: m.zaniew@ecm.uzz.zgora.pl
}

\begin{abstract}
The incidence of urolithiasis in the paediatric population has grown in recent years. Aim: The aim of this study was to analyse clinical symptoms, risk factors and diagnostic procedures in children with urolithiasis. Materials and methods: We conducted a questionnaire study (supplemented with an analysis of medical records) in a group of 49 children diagnosed with urolithiasis, including 17 patients from the department of paediatrics at the time of the first metabolic evaluation, and 32 patients hospitalised in a one-day department of paediatric urology prior to extracorporeal shock wave lithotripsy. Results: Urolithiasis occurred in children in the study group at the age of $9.3 \pm 4.9$ years and manifested with abdominal pain (69.4\%), vomiting (18.4\%) and haematuria (10.2\%); urolithiasis was diagnosed accidentally in $14.3 \%$ of patients. All patients developed renal stones (bilateral in $20.4 \%$ ); $28.6 \%$ of patients additionally presented with ureteral stones, and $6.1 \%$ with bladder stones. Urolithiasis was accompanied by urinary tract infection in $44.9 \%$ of patients. The most common risk factors for urolithiasis included positive family history (75.5\%), low fluid intake (51\%), urinary tract infection (42.9\%) and overweight/obesity (28.6\%). Among patients admitted for extracorporeal shock wave lithotripsy, only $65.6 \%$ of children underwent nephrological consultation. Slightly more than a half of these patients underwent metabolic diagnosis, with exhausted evaluation in 7 cases and incomplete metabolic assessment in 5 cases. The chemical composition of stones was analysed in $22.4 \%$ of patients. Conclusions: Abdominal pain and vomiting are the most common clinical symptoms in children with urolithiasis. The paper presents modifiable risk factors and shows the need for improvement in metabolic evaluation of urolithiasis.
\end{abstract}

Keywords: risk factors, diagnosis, children, urolithiasis, symptoms

W ostatnich latach obserwuje się wzrost częstości występowania kamicy układu moczowego w populacji dziecięcej. Cel: Cele niniejszej pracy obejmują analizę objawów klinicznych, czynników ryzyka oraz postępowania diagnostycznego u dzieci z kamicą układu moczowego. Materiał i metoda: Badanie ankietowe (uzupełnione o analizę dokumentacji medycznej) przeprowadzono w grupie 49 dzieci z rozpoznaniem kamicy układu moczowego, spośród których 17 osób było pacjentami oddziału pediatrii w trakcie pierwszorazowej diagnostyki metabolicznej, a 32 chorych było hospitalizowanych na jednodniowym oddziale urologii dziecięcej przed zabiegiem litotrypsji falą uderzeniową generowaną pozaustrojowo. Wyniki: Kamica układu moczowego wystąpiła u dzieci z badanej grupy w wieku 9,3 $\pm 4,9$ roku i objawiała się bólem brzucha (69,4\%), wymiotami (18,4\%) oraz krwiomoczem (10,2\%); u 14,3\% kamicę rozpoznano przypadkowo. U wszystkich pacjentów występowała nerkowa lokalizacja złogów (u 20,4\% obustronna); w 28,6\% przypadków złogi obserwowano dodatkowo w moczowodzie, a w 6,1\% w pęcherzu moczowym. U 44,9\% chorych kamicy układu moczowego towarzyszyło zakażenie układu moczowego. Najczęstszymi czynnikami ryzyka rozwoju kamicy były: dodatni wywiad rodzinny (u 75,5\%), mała podaż płynów (u 51\%), zakażenie układu moczowego (u 42,9\%) oraz nadwaga/otyłość (u 28,6\%). Wśród pacjentów przyjętych na zabieg litotrypsji falą uderzeniową generowaną pozaustrojowo jedynie $65,6 \%$ dzieci odbyło konsultację nefrologiczną. $Z$ tej grupy u nieco ponad połowy przeprowadzono diagnostykę metaboliczną, która w 7 przypadkach obejmowała szeroki zakres badań, natomiast w 5 przypadkach była niekompletna. U 22,4\% chorych wykonano analizę składu chemicznego kamienia. Wnioski: U dzieci z kamicą układu moczowego najczęstszymi objawami klinicznymi są bóle brzucha i wymioty. W artykule wskazano modyfikowalne czynniki ryzyka oraz wykazano konieczność poprawy w zakresie diagnostyki przyczyn metabolicznych kamicy. 


\section{INTRODUCTION}

$\mathrm{U}$ rolithiasis is a term used to describe hard, crystalline stones that form in the urinary tract. The heterogeneous etiopathogenesis of the disease leads to the formation of stones with a different chemical composition. Calcium stones account for the majority (70-80\%) of cases, uric acid and struvite (infectious) stones account for $10-15 \%$ and $5-7 \%$ of cases, respectively ${ }^{(1)}$. Urolithiasis should be treated as a symptom because many aetiological factors contribute to its development. Crystallisation of different substances, the so-called crystallisation promoters, which include, among others calcium, oxalates, uric acid, cystine, is the most common cause of stone formation. In turn, magnesium salts and citrates are among substances that inhibit crystallisation. Other promoters include low urinary volume and $\mathrm{pH}^{(1)}$, as well as anomalies of the urinary tract and neurogenic bladder ${ }^{(2)}$. The coexistence of several factors is often observed.

Urolithiasis affects both adults and children. It occurs in $1-5 \%$ of the general population, with male predominance. The prevalence of urolithiasis in the paediatric population is estimated to range from 1:1,000 to 1:7,000 inpatients ${ }^{(3)}$.

There are some differences in the manifestation of the disease depending on the age group. Paediatric urolithiasis is characterised by a variable clinical picture and high recurrence rates, which may lead to serious complications later in life $e^{(4)}$. The main causes of urolithiasis in children are metabolic defects such as hypercalciuria, hyperoxaluria, hyperuricosuria or hypocitraturia ${ }^{(1,4)}$, which are isolated in $70.7 \%$ of cases $^{(5)}$. Hypercalciuria is associated with hyperoxaluria and/or hypocitraturia in some patients. In recent years, there has been a noticeable growth in the incidence of this disease in the paediatric population, which may indicate the impact of environmental risk factors ${ }^{(4)}$. So far, there have been few scientific papers on urolithiasis in the Polish paediatric population. In this paper, we focus on the analysis of symptoms, risk factors and diagnosis in children with urolithiasis.

\section{MATERIALS AND METHODS}

The study was conducted between April 2019 and February 2020 by using questionnaires and was supplemented with

\begin{tabular}{|c|c|c|}
\hline Voivodeship & $\boldsymbol{n}$ & \% \\
\hline Lubusz Voivodeship & 15 & 30.6 \\
\hline Greater Poland Voivodeship & 9 & 18.4 \\
\hline Silesian Voivodeship & 7 & 14.3 \\
\hline Lower Silesian Voivodeship & 6 & 12.2 \\
\hline West Pomeranian Voivodeship & 4 & 8.2 \\
\hline Pomeranian Voivodeship & 3 & 6.1 \\
\hline Lesser Poland Voivodeship & 2 & 4.1 \\
\hline Subcarpathian Voivodeship & 1 & 2.0 \\
\hline Missing data & 2 & 4.1 \\
\hline
\end{tabular}

Tab. 1. Number of children included in the questionnaire by place of residence an analysis of the available medical records. A total of 49 children ( 29 girls and 20 boys) diagnosed with urolithiasis were qualified for the study. The study was run parallel in two centres. It included 17 patients from the Clinical Department of Paediatrics at the University Hospital in Zielona Góra, admitted for their first nephrological metabolic evaluation of urolithiasis, and 32 patients admitted to the One-Day Department of Paediatric Urology of the Wiśniowa Clinic in Zielona Góra for elective extracorporeal shock wave lithotripsy (ESWL). This department is a reference centre for urological treatment of paediatric patients with urolithiasis from all over the country.

We assessed anthropometric parameters [body weight, height, body mass index (BMI)], perinatal data (gestational age, birth weight), initial clinical symptoms, location and size of stones, recognised risk factors, including medications and/or supplements, diet used before stone formation, and diagnostic procedures in children with urolithiasis (nephrological diagnostics). In the latter case, only the group of patients admitted for ESWL $(n=32)$ was included in the analysis. When analysing the diagnostic scope, we used the terms "incomplete" and "complete" metabolic evaluation, with the latter reserved for diagnostic work-up that included, in addition to standard blood and urine tests, an assessment of urinary excretion of citrates and oxalates. In terms of risk factors such as fluid intake and diet, the assessment was subjective.

\section{Statistical analysis}

The results were expressed as numbers and percentages for qualitative variables, and as mean \pm standard deviation $(S D)$ for continuous variables.

\section{RESULTS}

\section{Clinical manifestations of urolithiasis}

The patients participating in the study came from many provinces. Children from the Lubusz Voivodeship were the largest group (30.6\%) (Tab. 1). Girls predominated in the study group $(n=29,60 \%)$. The mean age of study participants was

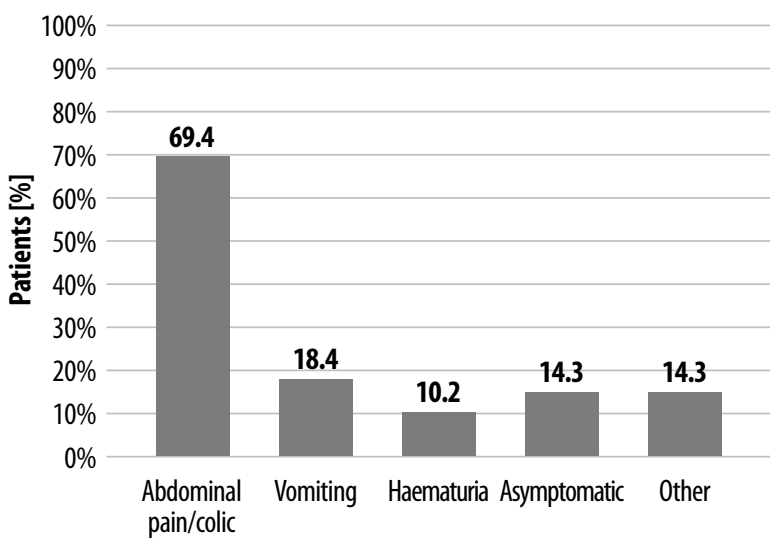

Fig. 1. Initial symptoms of urolithiasis in children 


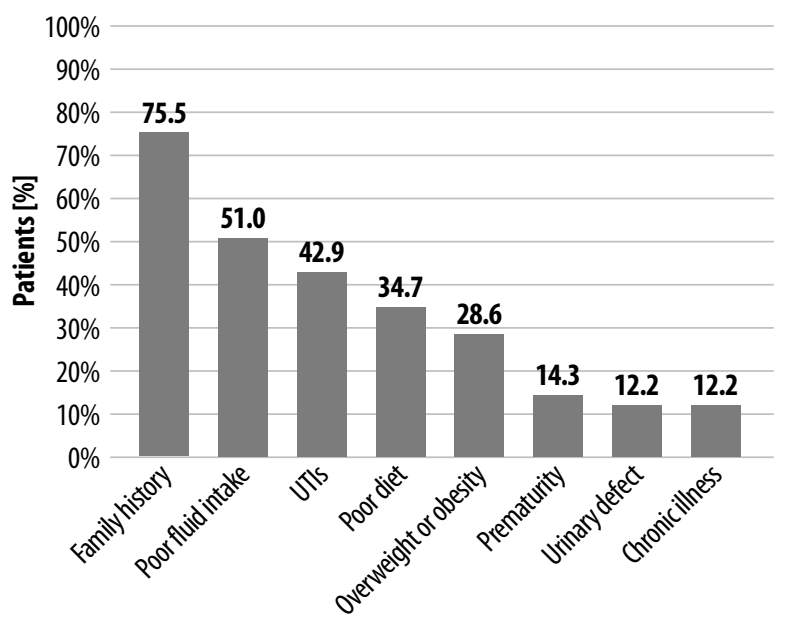

Fig. 2. Urolithiasis risk factors in the study group of 49 children

$12.3 \pm 5.0$ years, and the mean age at urolithiasis diagnosis was $9.3 \pm 4.9$ years. Urolithiasis manifested with abdominal pain (69.4\%), vomiting (18.4\%) and haematuria (10.2\%) (Fig. 1). There were 7 (14.3\%) asymptomatic children. The stones were visualised in a routine abdominal ultrasound (US) in 4 patients, and during a follow-up urological visit for reasons other than urolithiasis (nephrocalcinosis, dilation of the pelvicalyceal system and proteinuria) in 3 patients. Other symptoms in the remaining $7(14.3 \%)$ respondents included fever, urinary frequency and increased blood pressure. Urolithiasis overlapped with urinary tract infection (UTI) in $44.9 \%$ of patients. There was no gender-dependent difference in the incidence of UTIs. The analysis of medical records showed that some (12.2\%) patients developed abdominal pain before the diagnosis of urolithiasis, which resulted in hospital stay, during which 3 children were diagnosed with appendicitis and another 3 patients with premenstrual pain, functional abdominal pain and food poisoning, respectively. All patients had renal stones, including bilateral stones in $20.4 \%$ of patients. Ureteral and bladder stones were additionally found in $14(28.6 \%)$ and $3(6.1 \%)$ patients, respectively.

\section{Risk factors}

We also collected a history of possible risk factors (Fig. 2). A positive history was found in 37 (75.5\%) children. This was a first-degree relative (parents) in 25 patients, a second-degree relative (siblings/grandparents) in 19 patients, and a third-degree relative (great-grandparents/uncles) in 4 patients.

The mean BMI of respondents was $19.2 \pm 5.5 \mathrm{~kg} / \mathrm{m}^{2}$. There were $12(24.5 \%)$ overweight and 2 (4.1\%) obese children. We assessed the patients' diet from before the onset of urolithiasis. Poor eating habits were found in 17 (34.7\%) respondents. According to the parents, 14 children consumed significant amounts of sweets and dairy products, while 7 followed a diet low in fruit and vegetables. Parents of 25 (51\%) patients admitted that their children had low intake of fluids before the diagnosis. Twenty-one (42.9\%) children had a his- in 10 cases. Anomalies of the urinary tract were present in $6(12.2 \%)$ patients. These were hydronephrosis ( 3 children), horseshoe kidney, renal hypoplasia and duplication of the pelvicalyceal system. One child had a neurogenic bladder. Chronic diseases were reported in $6(12.2 \%)$ children, including cerebral palsy in 2 children, epilepsy in 3 children, and type 1 neurofibromatosis in 1 patient. Seven (14.3\%) children were born prematurely. A birth weight $<2,500 \mathrm{~g}$ (mean $3,116.1 \pm 667.9 \mathrm{~g}$ ) was reported for 9 children.

\section{Metabolic evaluation}

Fig. 3 shows the percentage of children who underwent diagnostics to identify the metabolic causes of urolithiasis. Among 32 patients admitted for ESWL, 21 (65.6\%) children had previously visited a nephrologist. Metabolic evaluation was performed in $12(57.1 \%)$ patients in this group. The assessment was exhausted in 7 (58.3\%) cases, and incomplete (urinary excretion of citrates and/or oxalates was not assessed) in $5(41.7 \%)$ cases. The chemical composition of stones was analysed in 11 (22.4\%) children from the study group.

\section{DISCUSSION}

The paper presents the clinical picture, risk factors and metabolic diagnosis based on the data from a representative group of children with urolithiasis.
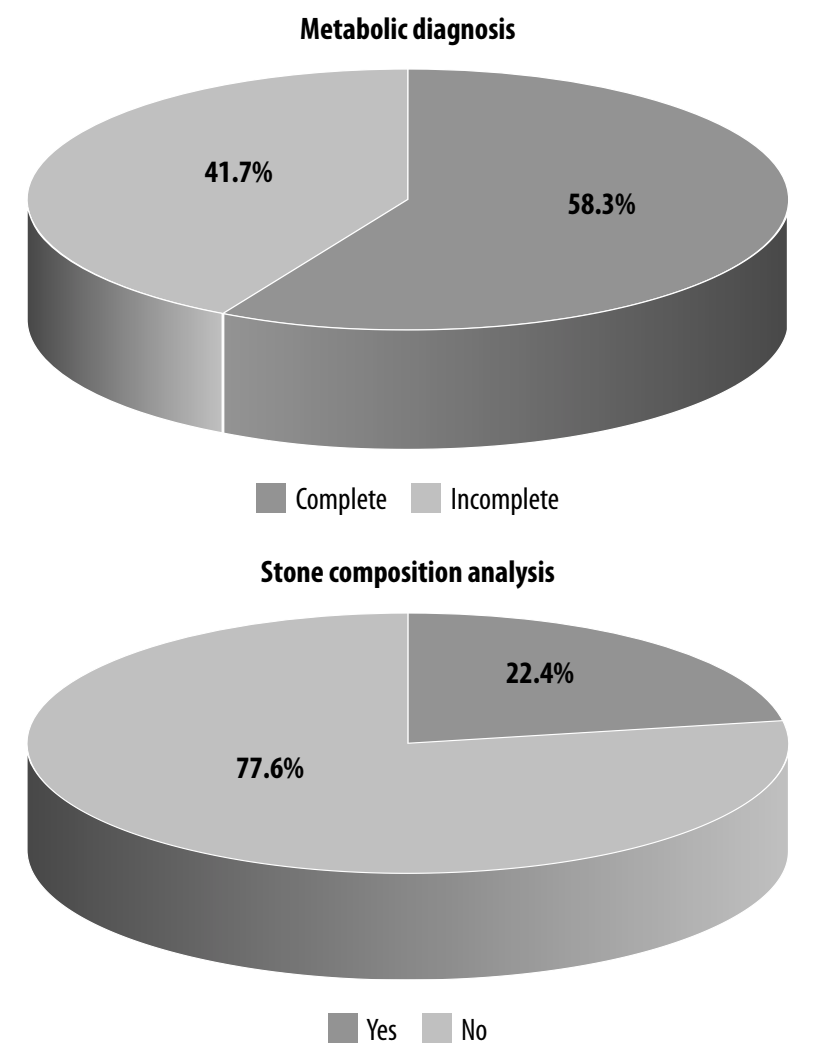

Fig. 3. The percentage of children who underwent diagnosis for metabolic causes of urolithiasis 
The clinical picture of paediatric urolithiasis is diverse and changes with age. As pointed out by Chu et al., renal colic, i.e. sudden onset severe pain originally located in the lumbar region and radiating towards the groin, may occur in older patients, whereas infants and younger children present with less typical symptoms ${ }^{(6)}$. Naseri conducted a retrospective study among 75 full-term and 2 preterm infants aged 4-60 days. The most common symptoms included restlessness and vomiting, with irritability observed in the vast majority of patients ${ }^{(7)}$. Issler et al. showed that only $32 \%$ of patients had a history of abdominal pain, $36 \%$ presented with UTI symptoms, and $27 \%$ had macroscopic haematuria ${ }^{(8)}$. In our study, abdominal pain was the most common symptom of urolithiasis (69.4\%). The difference in the prevalence of this symptom may result from the difference in the age of study groups. Furthermore, UTI was not considered a symptom of urolithiasis in this study due to difficulties in determining whether these were only symptoms typical of UTI related to stone excretion, or "true" UTI at the diagnosis. We showed a high incidence (44.9\%) of UTIs at the diagnosis. For comparison, other Polish authors reported a frequency of $2.9 \%{ }^{(5)}$. It cannot be ruled out that these were only symptoms typical of UTIs or that the diagnosis of UTIs was based on the frequently occurring urolithiasis-related leukocyturia in some children in the present study. It is believed that patients with urolithiasis may report painful urination, urinary incontinence or increased urination frequency ${ }^{(9)}$. Urolithiasis is asymptomatic in some patients $(13 \%)^{(7)}$, and the stones are often identified during diagnostic imaging for other reasons. In this study, such a diagnosis was made in $14.3 \%$ of patients. Considering the fact that the symptoms of urolithiasis are atypical in younger children, it seems reasonable to include this disorder in the differential diagnosis of non-specific abdominal pain, urination disorders, recurrent UTIs or haematuria ${ }^{(10)}$. It can be presumed that the abdominal pain was due to causes other than urolithiasis (including appendicitis) in some of the described patients (12.2\%). In these cases, incorrect diagnosis could have been the reason for delayed diagnostic work-up and, as a consequence, delayed treatment and prophylaxis.

Among the etiological factors, metabolic disturbances occur in approximately half of paediatric patients with urolithiasis ${ }^{(4)}$. It is extremely important to identify potentially modifiable metabolic risk factors due to the high risk of recurrence $(40 \%$ within 5 years and $75 \%$ within 20 years) $)^{(4)}$. In the case of metabolic disorders, appropriate prophylaxis should be implemented, including diet and pharmacotherapy. Initial assessment of urolithiasis risk factors can be performed during the first nephrological visit. Appropriate dietary and fluid management can be recommended already at this stage. However, our analysis shows that only $65.6 \%$ of children visited a nephrologist in the period between the diagnosis and ESWL. Metabolic diagnostics was performed in 12 patients in this group. Only slightly more than half of the patients underwent complete evaluation (including urinary excretion of oxalates and citrates). The remaining children underwent only basic diagnostic work-up, without any measurements of these substances.
According to long-standing recommendations, all paediatric patients should be qualified for diagnostics for metabolic predisposition to urolithiasis ${ }^{(1)}$. It should be emphasised that failure to determine the urinary excretion of oxalates and citrates may result in undiagnosed hyperoxaluria and/or hypocytraturia, which may consequently lead to recurrent urolithiasis and chronic kidney disease ${ }^{(1)}$. This is especially important in view of the reported increase in the incidence of low citrate excretion. According to some authors, hypocytraturia is even more common than hypercalciuria ${ }^{(4)}$, which so far has been considered the most common disorder in patients with urolithiasis. It is also worth noting in this paper that the stone composition was analysed in $22.4 \%$ of patients. This low percentage may be due to missing stone samples. However, from our experience, this could have resulted from difficulties with access to laboratories performing this type of analysis, the number of which has decreased in recent years. Nevertheless, efforts should be made to analyse stones whenever there are samples available.

A positive family history is another risk factor for urolithiasis. Children from families affected by urolithiasis are more likely to develop the disorder ${ }^{(1)}$. First-degree relatives of patients with urolithiasis are believed to be 2-16 times more likely to develop this disorder than the general population ${ }^{(4)}$. In our study, more than $70 \%$ of patients with urolithiasis had a positive family history of this disease. Up to $51 \%$ of the affected children had a parental history of urolithiasis.

In recent years, an increasing prevalence of urolithiasis has been observed. This is probably related to a poor diet and the increasing incidence of overweight and obesity ${ }^{(4)}$. An analysis of patients' records from The Kids' Inpatient Database in the USA showed that, as in adults, hypertension, diabetes and obesity are risk factors for urolithiasis in the paediatric population ${ }^{(11)}$. On the other hand, other analyses suggest that there is no proven relationship between the BMI and the incidence of urolithiasis in children ${ }^{(12,13)}$. In our study, almost $30 \%$ of children were overweight or obese. Therefore, we assessed the diet of children with urolithiasis. The obtained data showed an increased intake of proteins, poor intake of fruit and vegetables (vegetables were present in only one meal a day or were absent). These abnormalities and high salt intake (which was not assessed) are widely recognised promoters of urolithiasis ${ }^{(1,4)}$. Poor fluid intake is another well-known risk factor ${ }^{(1,4)}$. More than half of respondents had not consumed enough fluids before the diagnosis. It should be noted; however, that the analysis of the diet and fluid intake was not performed with the use of appropriate tools, but was only of a general nature. According to a review study, urolithiasis is of infectious nature in $1 / 4$ of patients. Urinary tract obstruction with urinary retention contributes to urolithiasis in $20 \%$ of children ${ }^{(4)}$. Almost half of our patients (42.9\%) had urolithiasis preceded by UTIs, while urinary tract malformations and neurogenic bladder were found in $14.3 \%$ of patients. Both urinary retention and an increased risk of UTI in the presence of urinary tract anomalies and dysfunctions predispose to urolithiasis ${ }^{(2,4)}$. It is believed to be both a cause and a complication of $\mathrm{UTI}^{(14)}$. 


\section{CONCLUSIONS}

Abdominal pain and vomiting, which, in the absence of typical symptoms, may delay the diagnosis, are the most common clinical manifestations in children with urolithiasis. We presented risk factors, among which low fluid intake, inadequate diet and excessive body weight require modification in these patients. Furthermore, we emphasised the need for prior nephrological consultation and improvement in diagnostics of metabolic causes of urolithiasis.

\section{Conflict of interest}

The authors do not declare any financial or personal links to other persons or organisations that could adversely affect the content of this publication or claim rights thereto.

\section{References}

1. Sikora P: Kamica układu moczowego i nefrokalcynoza. In: Kawalec W, Grenda R, Ziółkowska H (eds.): Pediatria. $2^{\text {nd }}$ ed., vol. I, PZWL, Warszawa 2013: 716-720.

2. Skrzypczyk P, Pańczyk-Tomaszewska M: Infectious urolithiasis. Pediatr Med Rodz 2019; 15: 33-37.

3. Novak TE, Lakshmanan Y, Trock BJ et al.: Sex prevalence of pediatric kidney stone disease in the United States: an epidemiologic investigation. Urology 2009; 74: 104-107.

4. Rodriguez Cuellar CI, Wang PZT, Freundlich $\mathrm{M}$ et al.: Educational review: role of the pediatric nephrologists in the work-up and management of kidney stones. Pediatr Nephrol 2020; 35: 383-397.

5. Wieczorkiewicz-Płaza A, Bieniaś B, Kusz M et al.: Clinical patterns of pediatric urolithiasis - a 4 year experience of a single center from south eastern Poland. Przegl Lek 2019; 76: 261-266.

6. Chu DI, Tasian GE, Copelovitch L: Pediatric kidney stones avoidance and treatment. Curr Treat Options Pediatr 2016; 2: 104-111.

7. Naseri M: Urolithiasis in the first 2 months of life. Iran J Kidney Dis 2015; 9: 379-385.

8. Issler N, Dufek S, Kleta R et al.: Epidemiology of paediatric renal stone disease: a 22-year single centre experience in the UK. BMC Nephrol 2017; 18: 136.

9. Copelovitch L: Urolithiasis in children: medical approach. Pediatr Clin North Am 2012; 59: 881-896.

10. Habbig S, Beck BB, Hoppe B: Nephrocalcinosis and urolithiasis in children. Kidney Int 2011; 80: 1278-1291.

11. Matlaga BR, Schaeffer AJ, Novak TE et al.: Epidemiologic insights into pediatric kidney stone disease. Urol Res 2010; 38: 453-457.

12. Çaltık Yılmaz A, Büyükkaragöz B, Oguz U et al.: Influence of body mass index on pediatric urolithiasis. J Pediatr Urol 2015; 11: e351-e356.

13. Kuroczycka-Saniutycz E, Porowski T, Protas PT et al.: Does obesity or hyperuricemia influence lithogenic risk profile in children with urolithiasis? Pediatr Nephrol 2015; 30: 797-803.

14. Szmigielska A, Skrzypczyk P, Pańczyk-Tomaszewska M: Epidemiology and types of urolithiasis. Pediatr Med Rodz 2019; 15: 22-25. 